\title{
Measures for diffusion of solar PV in selected African countries
}

\author{
Nygaard, Ivan; Hansen, Ulrich Elmer; Mackenzie, Gordon A.; Pedersen, Mathilde Brix
}

Published in:

International Journal of Sustainable Energy

Link to article, DOI:

10.1080/14786451.2015.1086768

Publication date:

2017

Document Version

Peer reviewed version

Link back to DTU Orbit

Citation (APA):

Nygaard, I., Hansen, U. E., Mackenzie, G. A., \& Pedersen, M. B. (2017). Measures for diffusion of solar PV in selected African countries. International Journal of Sustainable Energy, 36(7), 707-721.

https://doi.org/10.1080/14786451.2015.1086768

\section{General rights}

Copyright and moral rights for the publications made accessible in the public portal are retained by the authors and/or other copyright owners and it is a condition of accessing publications that users recognise and abide by the legal requirements associated with these rights.

- Users may download and print one copy of any publication from the public portal for the purpose of private study or research.

- You may not further distribute the material or use it for any profit-making activity or commercial gain

- You may freely distribute the URL identifying the publication in the public portal 


\title{
Measures for diffusion of solar PV in selected African countries
}

\author{
By \\ Ivan Nygaard, Ulrich Elmer Hansen, Gordon Mackenzie and Mathilde Brix Pedersen \\ UNEP DTU Partnership, DTU Management Engineering, \\ Technical University of Denmark

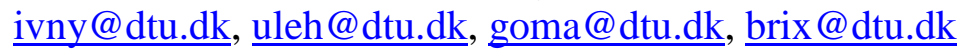 \\ Post print version of paper published in: \\ International Journal of Sustainable Energy (2015), pp.1-15. \\ Available at: \\ http://www.tandfonline.com/doi/full/10.1080/14786451.2015.1086768
}

\begin{abstract}
This paper investigates how African governments are considering supporting and promoting the diffusion of solar PV. This issue is explored by examining so-called 'technology action plans', which were main outputs of the Technology Needs Assessment project implemented in ten African countries from 2010 to 2013. The paper provides a review of three distinct but characteristic trajectories for PV market development in Kenya (private-led market for solar home systems), Morocco (utility-led fee-for service model) and Rwanda (donor-led market for institutional systems). The paper finds that governments' strategies to promoting solar PV are moving from isolated projects towards frameworks for market development and that there are high expectations to upgrading in the PV value chain through local assembly of panels and local production of other system elements. Commonly identified measures include support to: local production; financing schemes; tax exemptions; establishment and reinforcement of standards; technical training; and research and development.
\end{abstract}

\section{Keywords}

Measures, barriers, solar PV, Africa, Technology Needs Assessment 


\section{Introduction}

Recently, development projects have provided support to governments to facilitate technology transfer for climate change adaptation and mitigation. These include the Technology Needs Assessment (TNA) funded by the Global Environmental Facility (GEF). In the TNA project, which was implemented in ten countries in Africa in the period from 2010 to 2013, dedicated government committees have prioritized climate change mitigation technologies and developed action plans for the diffusion of the selected technologies.

Reports describing the results of the selection process, the barrier analysis and the resulting technology action plans have been issued by the participating countries and made available on the project website ${ }^{1}$, but so far there has been little analysis of which technologies were prioritized within and across regions (Africa, Latin America and South East Asia) or of barriers and measures for the transfer and diffusion of specific technologies (see e.g. UNFCCC, 2013). The African continent has abundant solar resources (Belward et al. 2011) and within the last few years, solar PV has under certain conditions become an economically viable option for both small-scale and large-scale applications in Africa (Bazilian et al. 2013; Huld et al. 2014; Hansen, Nygaard, et al. 2014). In spite of the great interest in solar PV in Africa in the TNA project, analyses of identified barriers and proposed measures for further diffusion of solar PV have not yet been carried out. Such analyses are needed however in order to obtain a greater understanding of the conditions under which solar PV may be scaled up to reach wider diffusion in African countries.

In order to fill this gap, this paper presents a cross-segment analysis of selected technologies addressing solar-related issues under the TNA across nine African countries and furthermore conducts a review of the identified barriers and measures proposed by governments.

The first section provides a short description of the TNA project and approach, followed by a description of the methods used to guide the analysis. The next section describes the different markets, products and typical owners of equipment. In order to illustrate distinct trajectories for the transfer and diffusion of PV technologies, this is followed by three country cases of PV diffusion. Finally, an analysis of the similarities and differences in barriers and measures across countries is presented before some brief forward-looking remarks are offered by way of a conclusion.

\section{The TNA project approach}

The objective of the TNA project was to identify and facilitate the transfer and diffusion of technologies for climate change mitigation and adaptation through the development of technology actions plans in non-annex 1 countries. The TNA project was funded by the GEF and implemented by UNEP in cooperation with the UNEP Ris $\varnothing$ Centre (URC) as part of the strategic programme for technology transfer agreed upon at COP14 in Poznan. The project was carried out in 36 countries in the period 2010-2013. ${ }^{2}$ This analysis for Africa covers Côte d'Ivoire, Kenya, Mali, Mauritius, Morocco, Rwanda, Senegal, Sudan and Zambia ${ }^{3}$.

The project followed an overall methodology consisting of the following basic steps: i) selection of priority technologies; ii) analysis of barriers; iii) suggesting measures to overcome barriers; and iv) the preparation of a government plan of action for facilitating

\footnotetext{
${ }^{1}$ www.tech-action.org (accessed 10.07.14)

2 More information about the project and its results is available at www.tech-action.org

${ }^{3}$ In the proposal, twelve countries are listed for the African region and the Middle East. The list only comprises nine countries for mitigation, as Ghana was only selected for adaptation technologies. Ethiopia was postponed to a later phase, and Lebanon is not included here, as it is situated in the Middle East.
} 
technology transfer and diffusion for specific technologies (Boldt et al. 2012). This approach was inspired by an understanding of technology innovation and diffusion as embedded in a specific institutional, political and regulatory environment and involving complex interactions among a variety of actors, such as universities, firms, government agencies, and financing bodies, as outlined in the frameworks of National Innovation Systems (Lundvall et al. 2002) and Technology Innovation System (TIS) approaches (Hekkert et al. 2007) ${ }^{4}$. The TIS approach has specifically been used for analysing innovation and diffusion of PV systems in a European context (Olson 2014), and in an African context in (Jacobsson 2013) for Rwanda and (Bleeker 2013) for Tanzania. In contrast to researchers doing extensive fieldwork as needed for the comprehensive TIS framework, the TNA methodology is based on activating and capturing stakeholders' knowledge of economic, political, social and cultural barriers for technology diffusion at country level and transforming this knowledge into national action plans for diffusion of specific technologies.

Although funded from external sources and following an overall methodology, the TNA project was a country-driven process led by a TNA committee comprising representatives from the most important line ministries responsible for finance, planning, energy, industry, agriculture and water, as well as non-government representatives from the private sector, civil society and the research community. The work of the TNA committee was coordinated by a TNA coordinator, most often from the ministry that is responsible for leading the climate negotiations. The work of the TNA committee was overseen by a project steering committee with high-level representatives from selected ministries. The TNA committee hired consultants to lead the prioritization of technologies, conduct the barrier analyses in cooperation with stakeholders from each sector and elaborate draft reports and plans to be discussed and endorsed by the TNA committee and later by the relevant line ministers. UNEP, in collaboration with the UNEP Ris $\varnothing$ Centre, had overall responsibility for project implementation in the countries. This included overall project management, methodology development, training and capacity-building, quality assurance and dissemination of results (Dhar et al. 2010)

\section{Methods}

This paper is based on systematic analysis of the outputs of the TNA project, a thorough literature review and personal insights by the authors gained through participation in the TNA project.

With respect to the prioritization of technologies in the countries, analysis of barriers and proposed measures, the paper draws on data from the TNA reports, the barrier analysis reports and the Technology Action Plan (TAP) reports available on the project webpage. Specific reference will be made to these reports where necessary.

In general, the reports from the TNA project do not include historical data on the diffusion of PV at national level. The historical analysis of PV diffusion in the three case counties and identification of the main drivers behind specific diffusion patterns are therefore based on a literature review of the academic literature, grey literature such as reports commissioned by donors and government institutions, and web-based news articles. Descriptive statistics across countries are mainly based on datasets available from the World Bank (WB 2012).

Besides these written sources, the paper draws on insights gained through the various stakeholder engagement platforms which were part of the TNA process. These included conferences, stakeholder workshops and training workshops in which, coordinators, consultants from participating countries, industry stakeholders, representatives from relevant

\footnotetext{
${ }^{4}$ For a more comprehensive discussion of frameworks for systems approaches to innovation and technological change see e.g. Coenen and Díaz López, (2010)
} 
authorities and key decision makers took part. Also the regional centre, ENDA, has contributed valuable context-specific knowledge from the six countries. When necessary, reference is made to specific personal communications.

\section{Market segments for PV}

When discussing barriers and measures for the diffusion of solar PV, it is important to acknowledge that, although PV products all produce electricity, the products are very different in size and are sold in different markets, at different scales, with different potential owners, and not least with different competing alternatives. This is illustrated in Table 1.

\section{Table 1: Solar PV market segments and their characteristics}

\begin{tabular}{|c|c|c|c|}
\hline $\begin{array}{l}\text { Technology and } \\
\text { products }\end{array}$ & Market segments & $\begin{array}{l}\text { Installed } \\
\text { capacity/size }\end{array}$ & Owners and buyers \\
\hline $\begin{array}{l}\text { Small pico-systems: } \\
\text { solar lanterns, LED } \\
\text { lamps, solar chargers }\end{array}$ & $\begin{array}{l}\text { Lighting and charging of batteries and } \\
\text { mobile phones in mainly non-electrified } \\
\text { areas }\end{array}$ & $1-10 \mathrm{~W}_{\mathrm{p}}$ & $\begin{array}{l}\text { Private (over the counter) } \\
\text { consumer devices }\end{array}$ \\
\hline $\begin{array}{l}\text { Solar home systems } \\
\text { (SHS) }\end{array}$ & $\begin{array}{l}\text { Off-grid electricity demand in private homes } \\
\text { in dispersed settlements, in smaller non- } \\
\text { electrified villages and on the outskirts of } \\
\text { electrified towns and villages far from } \\
\text { existing distribution lines }\end{array}$ & $10-100 \mathrm{~W}_{\mathrm{p}}$ & $\begin{array}{l}\text { Residential SHS } \\
\text { households), ESCOs }\end{array}$ \\
\hline $\begin{array}{l}\text { Stand-alone } \\
\text { 'institutional } \\
\text { systems' }\end{array}$ & $\begin{array}{l}\text { Institutions located in villages without grid } \\
\text { or mini-grid, or on the outskirts of grid- } \\
\text { electrified villages }\end{array}$ & $50-500 \mathrm{~W}_{\mathrm{p}}$ & $\begin{array}{l}\text { Government/municipal } \\
\text { procurement for public } \\
\text { institutions (schools, hospitals, } \\
\text { health clinics) }\end{array}$ \\
\hline Water pumping & $\begin{array}{l}\text { Waterpumping for village drinking water } \\
\text { supply or for irrigation }\end{array}$ & $50-5000 \mathrm{Wp}$ & $\begin{array}{l}\begin{array}{l}\text { Municipalities, } \\
\text { organisations and } \\
\text { farmers }\end{array} \text { arllage } \\
\text { private }\end{array}$ \\
\hline $\begin{array}{l}\text { Telecommunications } \\
\text { and tourism }\end{array}$ & $\begin{array}{l}\text { Powering telecom base receiver stations } \\
\text { (BTS), link sites, and remote tele-centres, } \\
\text { and basic electricity supply (mainly lighting) } \\
\text { for rural lodges and hotels }\end{array}$ & $0.2-15 \mathrm{KW}_{\mathrm{p}}$ & $\begin{array}{l}\text { Commercial companies in the } \\
\text { telecom and tourism sectors } \\
\text { (e.g. telecom service providers, } \\
\text { hotel owners, etc.) }\end{array}$ \\
\hline $\begin{array}{l}\text { Mini-grids (e.g. hybrid } \\
\text { PV-diesel ) }\end{array}$ & $\begin{array}{l}\text { Villages and towns located far from existing } \\
\text { grid }\end{array}$ & $5 \mathrm{~kW}-1 \mathrm{MW}_{\mathrm{p}}$ & $\begin{array}{l}\text { Utilities, cooperatives } \\
\text { (community-based), ESCOs } \\
\text { (village electrification projects) }\end{array}$ \\
\hline $\begin{array}{l}\text { Large-scale, } \quad \text { grid- } \\
\text { connected PV systems }\end{array}$ & $\begin{array}{l}\text { Expansion of production capacity in existing } \\
\text { grid }\end{array}$ & $1-50 \mathrm{MW}_{\mathrm{p}}$ & $\begin{array}{l}\text { Utilities, IPPs (incl. foreign } \\
\text { investors) }\end{array}$ \\
\hline
\end{tabular}

Source: Modified from Hansen et al. (2014).

This also means that, although there may be some similarities in the barriers and related measures for PV in general, there will be specific barriers and relevant measures in diffusing PV for each of the market segments. The TNA project countries were therefore advised to relate their choice of technologies to specific products or markets segments (e.g. large-scale grid-connected PV, PV water pumping or Solar Home Systems).

The nine countries in Africa which made action plans for climate change mitigation technologies selected on average about six technologies (a total of 52) for which they carried out barrier analysis and developed action plans. The technologies were related to sectors such as energy, industry, agriculture or waste that had been identified by the country teams.

Technologies such as solar home systems, solar PV for water pumping and large scale solar PV can be grouped into the broader category of solar power. Similarly other specific technologies can be categorized into larger 'standardized' technology groups, such as wind, 
geothermal power and biomass power. Table 2 shows the distribution of energy technologies according to such standardized technology groups, and indicates that nine technologies are in the solar power category, with six out of the nine countries represented. Technologies were selected according to criteria defined by the countries using a multi-criteria analysis (MCA) prioritization tool. One of these criteria could be 'added value', as in the case of Mauritius. Here a solar programme was already in the making, and the selection of solar power would therefore not add much value and was hence discarded in the TNA project, making room for other more 'needed' technologies, in this case wind. Nevertheless, selection of solar technologies by these countries remains a good proxy for the high interest in solar power in Africa in 2011 and 2012, when the prioritization of technologies was carried out.

Table 2: Selected mitigation technologies per country according to 'standard' technology categories

\begin{tabular}{|c|c|c|c|c|c|c|c|c|c|c|}
\hline Standardized technology group & 苞 & 忞 & 离 & 鹋 & $\begin{array}{l}\stackrel{8}{8} \\
\stackrel{0}{0} \\
\dot{e}\end{array}$ & 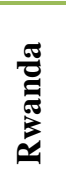 & 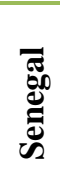 & 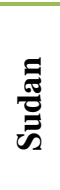 & 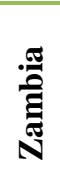 & $\stackrel{\pi}{\overparen{\sigma}}$ \\
\hline 2nd Generation biofuels & & & 1 & & & & & & & 1 \\
\hline Advanced coal technology & & & & & & & & 1 & & 1 \\
\hline Biodiesel & & & & & & & & & 3 & 3 \\
\hline Biogas & & & & & & & & 1 & & 1 \\
\hline Biomass gasification & & & & & & & & & 1 & 1 \\
\hline Biomass power & & & & & & & 1 & & & 1 \\
\hline Briquetting & 1 & & & & & & & & & 1 \\
\hline CFL's & & & & & & & & 1 & & 1 \\
\hline Combined heat and power & & & & & & 1 & 1 & & & 2 \\
\hline Efficient lighting systems & & & & & & & 1 & & & 1 \\
\hline Efficient stoves & & & 1 & & & & & 1 & 2 & 4 \\
\hline Geothermal power & & & & & & 1 & & & 1 & 2 \\
\hline Hydro power & 1 & & 1 & & & 1 & & & & 3 \\
\hline Less energy intensive products & & & & & & & 2 & & & 2 \\
\hline Methane gas utilisation & & 1 & & & & & & & & 1 \\
\hline Residential energy efficiency & & & & & 1 & & & & & 1 \\
\hline Solar heating/drying & & 1 & & & & & 1 & & & 2 \\
\hline Solar power & 2 & 1 & 1 & & 2 & 1 & 2 & & & 9 \\
\hline Tidal power & & & & & 1 & & & & & 1 \\
\hline Waste heat recovery & & & & 1 & & & & & & 1 \\
\hline Wind power & & & & 1 & & & 1 & & & 2 \\
\hline Energy & 4 & 3 & 4 & 2 & 4 & 4 & 9 & 4 & 7 & 41 \\
\hline
\end{tabular}

Source: Authors own elaboration based on TNA reports.

Table 3 shows the solar power technologies selected per country. In spite of the recommendation to focus on technologies tied to specific market segments, Mali and Senegal chose PV as a broad category and thus also including market segments such as large gridconnected and solar home systems (SHS). Rwanda selected large-scale solar power, while SHS were specifically chosen by Côte d'Ivoire and Kenya. PV-driven water-pumping was selected by Côte d'Ivoire, although in the final analysis this was merged with SHS, as the barriers and measures were seen to be very similar. Morocco, which is already well advanced in terms of its exploitation of solar power, chose to focus on research and development projects: concentrating PV for large power plants, and the production and use of molten salt for concentrating thermal solar power (CSP). 
Table 3: Selected solar power technologies per country

\begin{tabular}{|c|c|c|c|c|c|c|c|}
\hline Specific technologies & 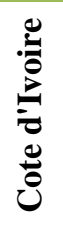 & 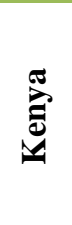 & $\stackrel{\bar{\pi}}{\sum}$ & $\begin{array}{l}\stackrel{\circlearrowright}{\circlearrowright} \\
\stackrel{0}{e} \\
\sum\end{array}$ & 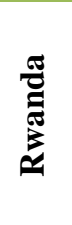 & 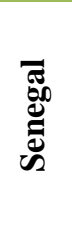 & 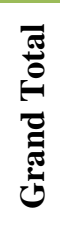 \\
\hline Photovoltaic solar energy & & & 1 & & & 1 & 2 \\
\hline Large Grid Connected PV & & & $*$ & & 1 & $*$ & 1 \\
\hline Solar Home Systems (SHS) & 1 & 1 & $*$ & & & $*$ & 2 \\
\hline PV driven water pumping & 1 & & & & & & 1 \\
\hline PV lanterns & & & & & & 1 & 1 \\
\hline Concentrating PV for power plants & & & & 1 & & & 1 \\
\hline Molten salt for thermal solar plants & & & & 1 & & & 1 \\
\hline Solar Power & 2 & 1 & 1 & 2 & 1 & 2 & 9 \\
\hline
\end{tabular}

\section{PV market development in the countries concerned}

The six countries included in the analysis have experienced very different policies and development trajectories with respect to the diffusion of solar PV.

This section first provides overviews of the status of PV diffusion in the six countries and of the policies already adopted. The diffusion of PV in these countries is related to the main socio-economic parameters. Following this overview, the background and drivers for diffusion in Kenya, Morocco and Rwanda are analysed in more detail in order to illustrate three very different diffusion trajectories.

\subsection{Socioeconomic context, incentives and diffusion of solar PV}

An overview of selected development indicators, PV capacity installed and applied measures for the promotion of solar PV in these six countries is provided in Table 4 below. 
Table 4: Key development indicators, installed solar PV capacity and incentives applied by 2013 in six African countries.

\begin{tabular}{|c|c|c|c|c|c|c|}
\hline & 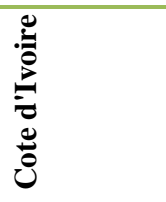 & 胥 & $\overline{\overline{\mathrm{E}}}$ & 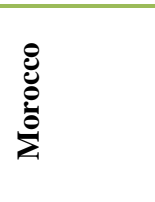 & 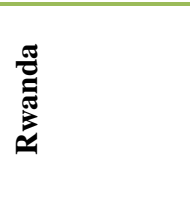 & 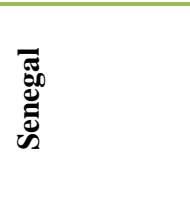 \\
\hline Population, Millions (2011) & 20.2 & 41.6 & 15.8 & 32.3 & 10.9 & 12.8 \\
\hline GDP per Capita, USD (2011) & 1,195 & 808 & 684 & 3,105 & 583 & 1,119 \\
\hline $\begin{array}{l}\text { National electrification rate } \\
\text { (2011) }\end{array}$ & $59.0 \%$ & $19.0 \%$ & $27.1 \%$ & $99.0 \%$ & $16.0 \%$ & $57.0 \%$ \\
\hline Rural electrification rate (2011) & $32.0 \%$ & $7.0 \%$ & $14.9 \%$ & $97.0 \%$ & $5.0 \%$ & $33.0 \%$ \\
\hline Mobile phone subsribtion (2011) & $86 \%$ & $68 \%$ & $68 \%$ & $113 \%$ & $41 \%$ & $73 \%$ \\
\hline $\begin{array}{l}\text { Installed PV capacity } \text { MWp } \\
\text { (2009) }\end{array}$ & NA & 6-8 MWp & $10 \mathrm{MWp}$ & $>9 \mathrm{MWp}$ & $<1 \mathrm{MWp}$ & $2.3 \mathrm{MWp}$ \\
\hline Installed PV Wp/capita & NA & 0.168 & 0.388 & 0.279 & 0.091 & 0.180 \\
\hline $\begin{array}{l}\text { Installed PV capacity } \text { MWp } \\
\text { (2012) }\end{array}$ & NA & $16 \mathrm{MWp}$ & $15 \mathrm{MWp}$ & NA & $>2 \mathrm{MWp}$ & 2.9 MWp \\
\hline Installed SHS total (2009) & NA & 300,000 & 100,000 & $>50,000$ & NA & 22,000 \\
\hline Installed SHS total (2012) & NA & 320,000 & 130,000 & $>50,000$ & NA & 22,000 \\
\hline Local assembly of panels (size) & None & $2.5 \mathrm{MWp} / \mathrm{y}$ & None & None & None & $25 \mathrm{MWp} / \mathrm{y}$ \\
\hline Feed in Tariff (FiT) & None & $2008 / 2012$ & None & None & None & TBI \\
\hline Excemptions from import duty & (Panels) & 1990 & 1999 & NA & None & TBI \\
\hline Excemptions from VAT & NA & 1990 & 2009 & NA & (LED only) & TBI \\
\hline
\end{tabular}

Source: Authors' compilation based on (WB 2012; Taoumi 2008; Hankins et al. 2009a; Hankins et al. 2009b; SIE-Senegal 2010; ONE 2010; DNE 2011; Ondraczek 2011; Ondraczek 2014; Jacobsson 2013; Meza 2013; Maïga 2012; Sarr et al. 2012; Da Silva 2014; Nygaard et al. 2012; Republic of Rwanda 2013; IEA 2013; SIESenegal 2013; SIE-Mali 2013; SIE-Mali 2009; ONE 2012)

Selected data from Table 4 above are illustrated graphically in Figures 1 and 2 below. Figure 1 shows a relatively high correlation between rural electrification rates and GDP. Mobile phone subscriptions (subscriptions per capita as a percentage) and GDP show a similar correlation, although mobile phone penetration is relatively high (above 40\%) in all countries. This indicates, not surprisingly, that rural electrification rates and mobile phone diffusion rates are to a large extent correlated with economic development.

Installed capacity of PV per capita ( $\mathrm{W}_{\mathrm{p}} /$ capita) and GDP is presented in Figure 2. Taking into consideration that statistical data on installed PV capacity may be uncertain, the figure shows a weak but generally positive correlation between installed capacity and GDP, thus indicating that economic development is a significant parameter for PV diffusion. The high installed capacity per capita in Mali is explained by a large number of donor programmes supporting PV for institutions, water pumping and individual use. Taking into consideration the relatively high uncertainty on statistics, the installed capacity per capita in Mali in 2009 was outstanding compared to the other countries. 
Figure 1. Rural electrification rate (2011) and mobile phone subscriptions as percentages (2011) related to GDP per capita (2011).

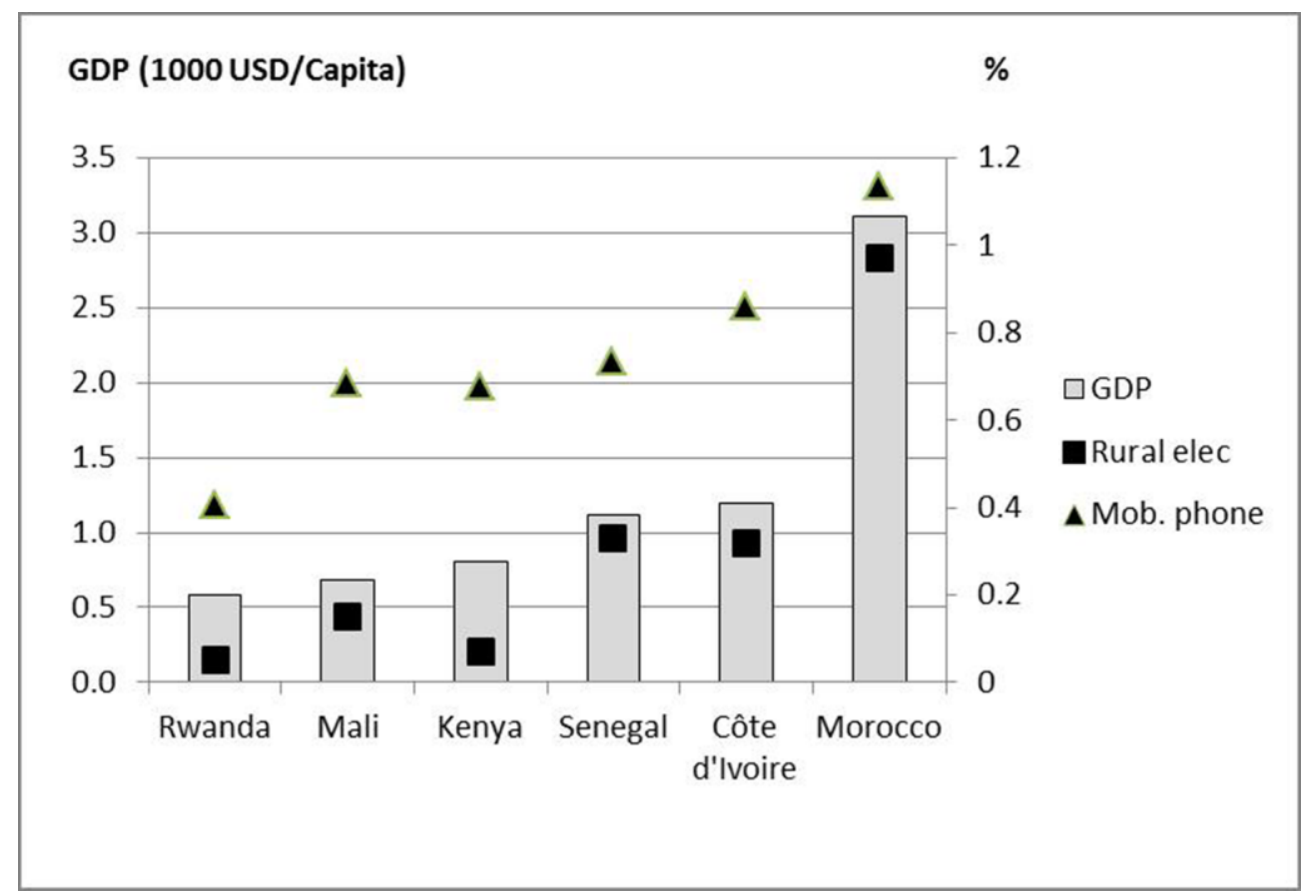

Source: Based on data from Table 4.

Figure 2. GDP per capita (2011) and installed PV capacity (2009) in $\mathrm{W}_{\text {p }}$ per capita.

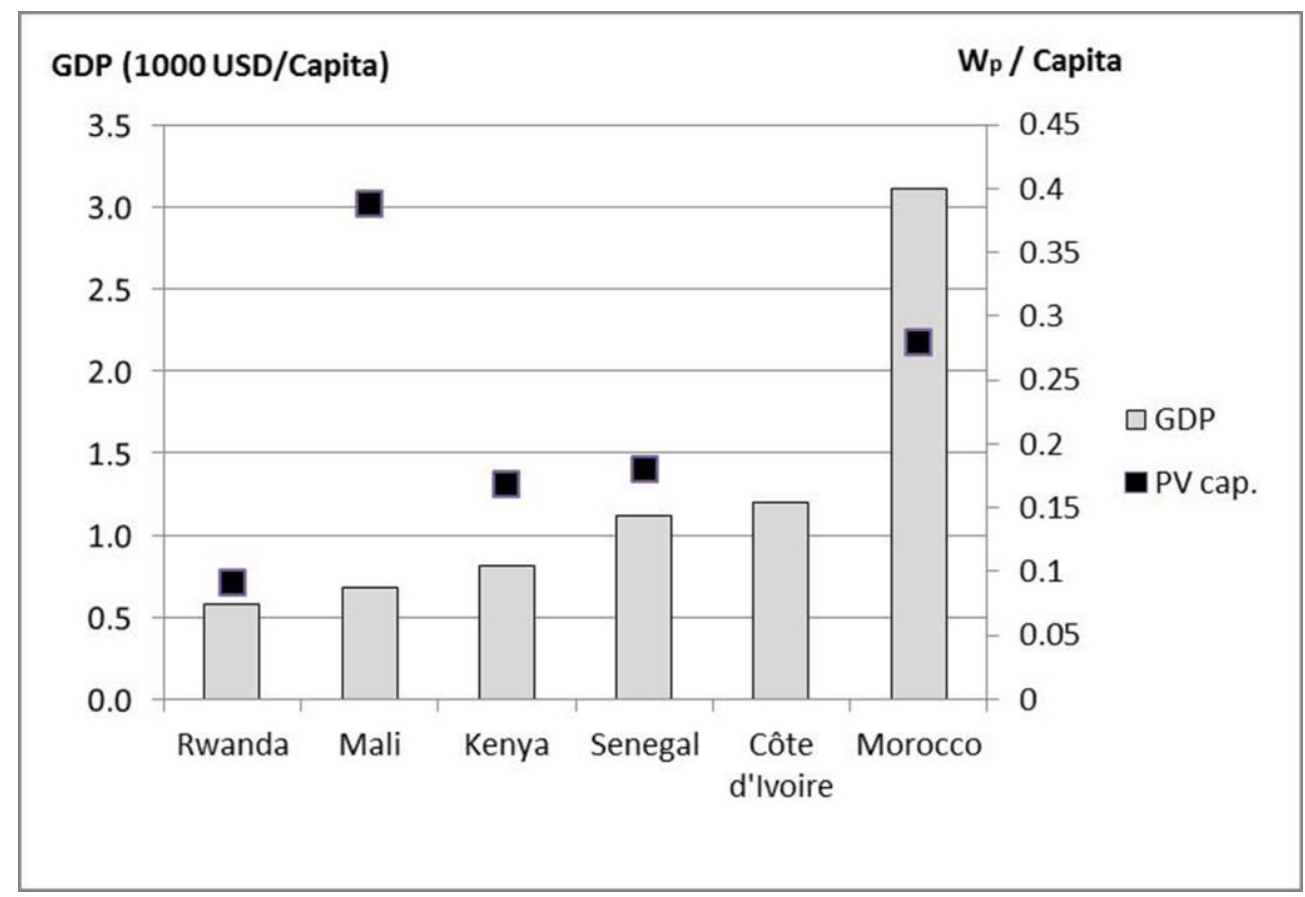

Source: Based on data from Table 4. Mean values of interval is used for Kenya.

Mali and Kenya are the only countries to have introduced exemptions from import duties and VAT on solar panels at an early stage (Table 4). It is remarkable that both countries have a high penetration of PV per capita compared to GDP, suggesting that exemptions from duties 
and taxes have a significant effect. This would, however, need more analysis to be substantiated. As we shall see in the following three country cases, there are a number of other drivers that may have determined the diffusion trajectories.

\subsection{Kenya}

Kenya today boasts a solar market that is one of the most mature and best established in Africa. Its origins date back to the 1970s, when the Kenyan government started to use solar energy as a means to power signalling and broadcasting installations in remote areas. Subsequently, from the 1980s onwards, international donors (and NGOs) began to play a larger role by including solar in their development programmes by means of workshops, training programmes and demonstration projects that contributed to generating a demand for PV in Kenya (Acker \& Kammen 1996; Hankins 2000). While government and donor programmes have continued to play an important role in promoting PV in Kenya, this support has gradually been phased out in parallel with the establishment of a private market that slowly started to emerge during the 1980s with the first established suppliers of solar equipment to customers in rural areas (Jacobson 2007).

During the 1980s and 1990s, this private market grew rapidly along with a continued reduction in PV system prices, which led to a genuine boom period during the late 1990s (Hankins et al. 2009a). Thus, while overall installed PV capacity was estimated at around 1.5 MW peak $\left(\mathrm{MW}_{\mathrm{p}}\right)$ in the early 1990s, with approximately two thirds installed in institutional systems (Acker \& Kammen 1996), the Kenyan market had more than doubled by 2000 (to approximately $3.9 \mathrm{MW}_{\mathrm{p}}$ ), with around $75 \%$ of the installed capacity in households (MonerGirona et al. 2006). A decade later, the overall market had reached between 8 and $10 \mathrm{MW}_{\mathrm{p}}$ of installed capacity (Hankins et al. 2009a). After the comprehensive market review in 2009, information about development in installed capacity has been sporadic. Ondraczek (2014) estimates that 320,000 SHS were in operation in 2010 and refers to Ramboll (2012) claiming $16 \mathrm{MW}_{\mathrm{p}}$ in operation in 2012. Tobias Cossen from GIZ estimates $20 \mathrm{MW}_{\mathrm{p}}$ in operation in November 2013 (Meza 2013).

Since 2009 the increase in capacity has mainly been in the market segment for SHS. Ondraczek (2013) estimates that 320,000 SHS have been installed as of 2012, and Da Silva (2014) claimed that about 400,000 units were installed in 2014. However, the use of PV for grid connection and in mini-grids has so far been limited. According to Ondraczek (2013) and PV Magazine (Meza 2013) only three systems with sizes respectively of 60, 72 and $515 \mathrm{~kW}$ were connected to the grid.

These developments have spurred the emergence of a substantial supplier network of PV systems and associated components, such as batteries and inverters, making Kenya a regional PV-manufacturing hub (Moner-Girona et al. 2006; Hankins et al. 2009a; Hankins 2000). In 2010, Ubbink, a joint venture of the German group Centrotec and Cloride Exide, set up the first solar module manufacturing company in East Africa, located in Naivasha, Kenya, with the objective of producing 20-30,000 PV modules per year (Ondraczek 2011). While actual production output is unknown, according to the company website production of off-grid modules from 13-60 $\mathrm{W}_{\mathrm{p}}$ and larger modules up to $250 \mathrm{~W}_{\mathrm{p}}$ started in $2011^{5}$.

The Government of Kenya has high expectations regarding the future of PV in Kenya. According to the National Energy Policy, Kenya expects installed capacity to grow as follows: $100 \mathrm{MW}_{\mathrm{p}}$ by 2016, $200 \mathrm{MW}_{\mathrm{p}}$ by 2022 and $500 \mathrm{MW}_{\mathrm{p}}$ by 2030 (Government of Kenya 2012).

Feed-in tariffs (FiTs) for power from renewable forms of energy were first introduced in March 2008. The last review took place in December 2012. The scheme is technology-

\footnotetext{
${ }^{5}$ Company webpage http://www.ubbink.co.ke/ accessed 10.07.14
} 
specific, and the tariff for solar is fixed at US\$0.12 per kilowatt hour for installation connected to the grid and US\$0.20 for mini-grids (ME 2012). The FiT has spurred interest from foreign investors in the development of large-scale, grid-connected solar plants, which is recognizable in a number of projects currently under development. Beside four projects already installed (all of which are $<1 \mathrm{MW}_{\mathrm{p}}$ ), two $50 \mathrm{MW}_{\mathrm{p}}$ plants are under development for which power purchase agreements and government approvals have been obtained (Hansen, Nygaard, et al. 2014).

\subsection{Morocco}

In Morocco the installation of solar home systems has mainly been driven by the rural electrification scheme led by the Moroccan utility, Office National de l'Electricite (ONE), which brought the rural electrification rate from a level of less than $20 \%$ in 1995 to more than $98 \%$ in 2013. The high rural electrification rate was mainly achieved through gridconnection, but in off-grid areas more than 50,000 houses were supplied by individual solar home systems. ${ }^{6}$ The Moroccan delivery model for SHS is a fee-for-service model. This means that installations are owned by the national utility, ONE, and, as in the case of grid-connected electricity provision, consumers pay a monthly fee for electricity. In the Moroccan case, through a competitive bidding process, ONE has engaged with international Energy Service Companies (ESCOs), such as TEMASOL, a joint venture between the French companies Total and EDF which has been responsible for installation, maintenance and the collection of user fees (Allali 2011). The SHS programme has been subsidized with up to $90 \%$ of investment by ONE. The source of the subsidy is partly internal funding (cross-subsidies) and partly loans from international finance institutions (Saddouq 2009).

Other initiatives, such as the Photovoltaic Market Transformation Initiative (PVMTI) funded by the GEF, was also implemented in Morocco. In contrast to Kenya, where this initiative supported the market-led approach, in Morocco this project supported one of the smaller ESCOs working under the ONE rural electrification programme (Magradze et al. 2007).

Until 2012 Morocco had only two smaller grid-connected PV systems of $200 \mathrm{~kW}$ in the Promasol programme, but unlike most other African countries, Morocco has shown great interest in concentrating solar power. The Mathar thermo-solar combined-cycle power plant, with a total capacity of $470 \mathrm{MW}$, was inaugurated in 2010, being built, owned and operated by ONE. The plant was supplied by natural gas, but $20 \mathrm{MW}$ of its power could be attributed to CSP. Morocco has recently launched the Moroccan integrated solar project, which aims at a capacity of $2,000 \mathrm{MW}_{\mathrm{p}}$ by 2020 at five sites. The programme, which will comprise both PV and CSP technologies, has started construction of the first 160 MW CSP plant at Quarzazate, which is expected to be in operation in 2015 (Cîrlig 2013). In order to achieve the 2,000 MW target, the government plans to initiate a bidding round for new tenders to develop additional projects under the MSP, which include a $400 \mathrm{MW}_{\mathrm{p}}$ plant next to the Ain Beni Mathar plant (to be commissioned in 2016), a $500 \mathrm{MW}_{\mathrm{p}}$ plant in Foum Al Ouad (to be commissioned in 2017), a $500 \mathrm{MW}_{\mathrm{p}}$ plant in Boujdour (to be commissioned in 2018) and a $100 \mathrm{MW}_{\mathrm{p}}$ in Sebkhat Tah (to be commissioned in 2019) (Hansen, Nygaard, et al. 2014).

\subsection{Rwanda}

According to Hankins et al. (2009), in 2009 Rwanda was at an 'early stage market of small players that is poorly integrated into the global and regional solar energy industry'. At the time there were only about six to eight companies competing in a small market of $60 \mathrm{~kW}_{\mathrm{p}}$ per

\footnotetext{
${ }^{6}$ ONE website as of June 2014 http://www.one.org.ma/
} 
year. Most of the business was financed by donors and mainly served government clinics and schools. At the same time Hankins et al. (2009a) note that there is an important future market of up to $4.2 \mathrm{MW}_{\mathrm{p}}$ for private households. Due to the low rate of competition, consumer prices are reported to be high compared to other countries in the region, and surprisingly there was limited spillover from neighbouring Tanzania and Kenya. In spite of the above, Rwanda hosted the largest grid-connected installation in the region, a $250 \mathrm{~kW}_{\mathrm{p}}$ pilot plant installed in 2008 (Hankins et al. 2009b). However, according to Jacobsen (2013), there has been an important increase in activities since 2009. In his 2012 research, he counted 21 companies compared with six to eight in 2009. Many of them are operating in both the SHS market and the newly established pico market for lanterns and mobile chargers, and he found that annual sales grew from about 50-100 $\mathrm{kW}_{\mathrm{p}}$ in 2009 to about $1400 \mathrm{~kW}_{\mathrm{p}}$ in 2011 and $2012 .{ }^{7}$

Again according to Jacobsen (2013), the government only reluctantly supported PV until 2012. The influential Rwanda Vision 2020 report had a strong focus on renewable energy, but without including targets for PV (Republic of Rwanda 2000). Likewise the feed-in tariff, discussed since 2006, did not include PV. The only government support, except for the donor programmes for institutions, schools and health centres, was a VAT exemption for LED lamps, which mainly helped the market for solar lanterns. Jacobsen (2013) therefore talks about a paradigm shift in government around 2012. This is visible in the Economic Development and Poverty Reduction Strategy, which states 'that the government in partnership with the private sector will support the rapid dissemination and sales of solar home systems (up to 1.2 million units) through a large-scale awareness programme of the benefits of solar power for rural households', and further that 'the regulatory environment and standard on solar products will be reviewed were appropriate' (Republic of Rwanda 2013).

The effect of these promises on the market for SHS to rural households remains to be seen, but interestingly, in parallel with the TNA process focusing on large-scale grid-connected PV (2011-2013), a group of international investors has closed a PPA with the national utility in 2013 (Hall 2013) and in early 2014 reached financial closure for a $8.5 \mathrm{MW}_{\mathrm{p}}$ grid-connected project (Willis 2014). Further, it has been reported (Reuters 2014) that, in May 2014 the government of Rwanda also signed an agreement with a consortium consisting of South Africa-based renewable energy company TMM Renewables, Malta-based Gesto Energy Africa and Rwanda-based solar company 3E Power Solar for the construction of a $10 \mathrm{MW}_{\mathrm{p}}$ PV power plant in the Kayonza district of Rwanda's Eastern Province.

\subsection{Comparing approaches in the three cases}

These three cases illustrate three different transfer and diffusion strategies. Kenya presents one of the most mature markets for solar home systems in Africa and is an example of a mainly private, market-led approach. Morocco is another leading country in the region when it comes to the diffusion of PV. In Morocco, solar PV diffusion has mainly been driven by a utility-led rural electrification programme, which has provided PV-produced electricity using a fee-for-service model. However, in spite of the relatively high number of SHS in Kenya, this corresponds to only about 5\% of the rural population using PV electricity (Ondraczek 2011). As the rural electrification rate is 7\%, there is still a large market for SHS. This is in contrast to Morocco, where the rural electrification rate of almost $100 \%$ has left little room for a private market for SHS. Morocco has subsequently initiated a plan for large-scale grid connection, focusing mainly but not exclusively on CSP, and it is currently working on developing a plan for grid-connected roof-top PV systems (Seck et al. 2014).

The impressive development in Kenya in terms of the highest number of SHS diffused on the continent is less impressive when these installations are converted to installed capacity per

\footnotetext{
${ }^{7}$ With reference to a study based on import data (Marge 2013).
} 
capita and seen in relation to GDP, as illustrated in Figure 2 above. In this context, Kenya is only slightly above the trend for installed capacity in the other countries. Likewise Figure 2 shows that per capita PV capacity in Morocco is low compared to GDP, in spite of being remarkable in absolute terms.

Both Kenya and Morocco are examples of countries where PV has increasingly been diffused over a number of years ${ }^{8}$. Rwanda, on the other hand, has experienced slow progress in solar PV, which has mainly been supported by donor programmes to rural institutions such as schools and health centres, though a political paradigm shift can be observed in the last couple of years. This paradigm shift follows a more general trend in African countries, due to the fact that PV has now finally reached a cost level that makes it economically feasible or 'almost' feasible on most markets under certain conditions. Under these circumstances, properly created measures and incentives in terms of a comprehensive enabling framework are important to ensure a smooth market development.

\section{Identified barriers and measures for diffusion of solar PV}

This section reviews the study of barriers for diffusion of solar PV and the possible measures to overcome these barriers in country studies of Côte d'Ivoire, Kenya, Mali, Rwanda and Senegal (IEA 2013; MESD 2013; MEAT 2012; NEMA 2013; Republic of Rwanda 2012; MEDD 2012; MEMEE 2012). As already described in section one and two, Morocco is not included in this analysis as it had selected technologies that are at the research level and hereby facing different barriers. The findings are summarized in Table 5.

\subsection{Barriers}

The most common barriers are described below, both in general and for each of the main market segments

General barriers for PV diffusion

- High upfront costs. This was partly explained by low volume, few suppliers and low competition, partly by the fact that equipment is imported with high transport costs, and especially because equipment in most countries was subject to VAT and import duties (all countries).

- High interest rates and difficult access to capital (all countries).

- Low quality products. This was mainly seen to be due to a lack of standards or to poorly enforced standards (Rwanda, Kenya and Senegal).

- Low level of technical skills for installation and maintenance, and low level of engineering expertise in relation to large-scale grid-connected systems and hybrid systems for minigrids (Rwanda, Mali, Kenya and Senegal).

- Low level of $R \& D$ in solar PV at the national level (Rwanda, Mali, Kenya and Senegal).

Large-scale grid connection (technology selected in Rwanda, Mali and Senegal)

- High production costs for PV electricity compared to the alternatives (Rwanda and Senegal).

- Little experience at national level, i.e. none or few pilot and demo-projects (all).

- No fixed selling prices for electricity (Rwanda and Senegal).

Solar home systems (technology selected in Mali, Kenya, Senegal and Côte d'Ivoire)

- Low purchasing power by rural population (all).

\footnotetext{
${ }^{8}$ For an overview of delivery models for solar PV, see e.g. Nygaard (2009).
} 
- Little knowledge about PV among consumers (Kenya and Côte d'Ivoire).

- Poor delivery and service network in rural areas (Kenya).

\subsection{Measures}

The most common measures are described below, both in general and for each of the main market segments

\section{General measures}

- Support to local production. All countries - except for Kenya and Senegal, where local production is already established - suggest measures to support local production. This comprises initiatives from support to information, field visits and network formation in Rwanda, via support to public-private partnerships in Mali to support to and training of small and medium enterprises (SMEs) in Côte d'Ivoire. Support is apparently based on a belief that local production will reduce prices and generate income and jobs locally.

- Financing schemes. All countries propose support to financing schemes, with a combination of guarantees and low interest rates, addressing both costs and access to finance.

- Tax exemptions. Mali and Kenya already have exemptions from VAT and import duties. Côte d'Ivoire has exemption from import duties, and Senegal is awaiting the implementation of a law from 2010 stipulating exemptions. The other countries have proposed exemptions. To support the newly established local assembly of panels, Senegal is also proposing removing import taxes from 'elements' of solar panels, such as wafers, glass and aluminium frames, which are inputs to the assembly plant.

- Establishment and reinforcement of standards. While most countries see low-quality products as a barrier, only Kenya and Senegal have proposed taking action. Kenya is calling for a strengthening of general measures against corruption, while Senegal proposes support to the bureau of standards.

- Support to technical training. This measure is proposed in all countries except for Mali, which, on the other hand - and like Côte d'Ivoire - proposes training for employees in the finance sector.

- Support to $R \& D$. Strengthening of research and development is proposed by all countries except Côte d'Ivoire. A new research centre is proposed in Rwanda, revival of an old research centre in Mali, while Kenya and Senegal suggest more support to existing research and development centres.

Large-scale grid-connected (technology selected in Rwanda, Mali, Senegal)

- Feasibility study, pilots and demo projects are proposed in Rwanda, Mali and Senegal.

- Standard PPAs and feed-in tariffs are proposed in Rwanda and Senegal.

Solar Home Systems (technology selected in Mali, Kenya, Senegal and Côte d'Ivoire)

- Subsidies for PV in rural electrification are proposed in Kenya, while elaboration of wider 'incentives' is suggested in Mali, Senegal and Côte d'Ivoire.

- Awareness raising in terms of information activities for rural population is proposed in Kenya and Senegal, while in Côte d'Ivoire awareness raising is proposed to address the supply side, such as importers, the financing sector and technical personnel. 
Table 5: Barriers and proposed measures for diffusion of solar PV in Rwanda, Mali, Kenya and Senegal and Cote d'Ivoire

\begin{tabular}{|c|c|c|c|}
\hline & & Barriers & Proposed measures \\
\hline \multirow{5}{*}{$\begin{array}{l}\text { General barriers for PV } \\
\text { diffusion }\end{array}$} & \multirow[t]{2}{*}{ Financial barriers } & High upfront costs & \multirow{2}{*}{$\begin{array}{l}\text { Support to financing } \\
\text { schemes. } \\
\text { - Tax exemptions. }\end{array}$} \\
\hline & & $\begin{array}{l}\text { High interest rates and difficult } \\
\text { access to capital }\end{array}$ & \\
\hline & Technical barriers & Low quality products & $\begin{array}{l}\text { Establishment } \\
\text { reinforcement of standards }\end{array}$ \\
\hline & \multirow[t]{2}{*}{ Knowledge barriers } & $\begin{array}{l}\text { Low level of technical skills } \\
\text { and low level of engineering } \\
\text { expertise }\end{array}$ & $\begin{array}{l}\text { - Support to technical training } \\
\text { - Support to local production }\end{array}$ \\
\hline & & Low level of R\&D & - Support to R\&D \\
\hline \multirow{3}{*}{ 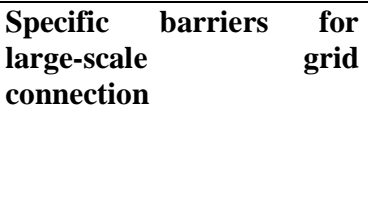 } & \multirow[t]{2}{*}{ Financial barriers } & $\begin{array}{l}\text { High production costs for PV } \\
\text { electricity }\end{array}$ & \multirow[t]{2}{*}{$\begin{array}{l}\text { - Standard PPAs and feed-in } \\
\text { tariffs }\end{array}$} \\
\hline & & $\begin{array}{l}\text { No fixed selling prices for } \\
\text { electricity }\end{array}$ & \\
\hline & Knowledge barriers & $\begin{array}{l}\text { Little experience at national } \\
\text { level }\end{array}$ & $\begin{array}{l}\text { - Feasibility study, pilot and } \\
\text { demo projects }\end{array}$ \\
\hline \multirow[t]{3}{*}{$\begin{array}{l}\text { Specific barriers for solar } \\
\text { home systems }\end{array}$} & Financial barriers & $\begin{array}{l}\text { Low purchasing power by rural } \\
\text { population }\end{array}$ & $\begin{array}{l}\text { - Subsidies for PV in rural } \\
\text { electrification }\end{array}$ \\
\hline & Knowledge barriers & $\begin{array}{l}\text { Little knowledge about PV } \\
\text { among consumers }\end{array}$ & - Awareness raising \\
\hline & Structural barriers & $\begin{array}{l}\text { Poor delivery and service } \\
\text { network in rural areas }\end{array}$ & \\
\hline
\end{tabular}

Source: Authors' own elaboration based on TNA reports.

Some of these measures have already been implemented, while others are still awaiting approval or further action. We have not done a full survey of which proposals have been implemented by mid-2015, but we know that Technology Action Plans (TAPs) are currently being pursued in some countries, such as e.g. Morocco, where the TAP on solar PV is followed by the development of two NAMAs (National Appropriate Mitigation Actions) for a grid-connected solar PV roof top programme and a programme for solar PV for water pumping in rural areas. Similarly in Senegal, where the TAP on solar power is being followed by a NAMA for increased use of solar PV in rural areas. ${ }^{9}$ We have also noted that a few of these measures have even been overtaken by activities on the ground and already seem obsolete, such as the proposed feasibility studies, pilot and demonstration projects for largescale solar power in Rwanda, Mali and Senegal. These proposed first steps toward implementation have since 2012-2013 been superseded by large-scale fully commercial gridconnected installations. Rwanda installed $8.5 \mathrm{MW}_{\mathrm{p}}$ in 2013, Mali has signed PPA for $30 \mathrm{MW}_{\mathrm{p}}$ and a $50 \mathrm{MW}_{\mathrm{p}}$ solar installations in June $2015^{10}$, and Senegal is in the advanced stages of signing a PPA for $50 \mathrm{MW}_{\mathrm{p}}$ of grid-connected solar power ${ }^{11}$.

\section{Concluding remarks}

This paper has, through an analysis of solar PV technologies selected by countries participating in the TNA project, contributed to providing new knowledge about identified barriers and proposed measures to solar PV diffusion by five countries in Africa. This analysis has increased the understanding of barriers and measures for solar PV diffusion

\footnotetext{
${ }^{9}$ http://www.lowcarbondev-support.org/PARTICIPATING-COUNTRIES/Morocco http://www.lowcarbondev-support.org/PARTICIPATING-COUNTRIES/Senegal

${ }^{10}$ Personal communication 25.06.15 with Mamadou Saliou Sow, Director R20, Dakar, Senegal

${ }^{11}$ Personal communication 26.06.15 with Ousmane Fall Sarr, Head of the Studies and Information System Unit at the Senegalese Rural Electrification Agency (ASER), Dakar Senegal.
} 
across countries and different market segments compared to the existing research, which focuses narrowly on the diffusion of solar home systems in individual countries. As a country-led process the results from the TNA provide good indications of country-level priorities in relation to solar PV diffusion. The African countries which participated in the TNA project have shown high levels of interest in solar PV technologies. $25 \%$ of the action plans for energy-related mitigation technologies were focusing on solar power, and six out of nine countries had selected solar power as one of their mitigation technologies. An even more tangible sign of the high level of interest is that local production has been established in Kenya and Senegal, and that this is also high on the agenda for the other three countries in the analysis. The most common measures were support to i) local production, ii) financing schemes, iii) tax exemptions, iv) establishment and reinforcement of standards, v) technical training, and vi) research and development.

The analysis above, coupled with the experience drawn from capacity-building and training courses in the TNA project in which the authors were involved, suggest some concluding remarks regarding future donor support to PV diffusion in Africa.

First, we see that direct donor support to projects providing and installing equipment is and will be vanishing. From being a niche relying on donor-supported equipment, PV is currently a viable or 'almost' viable alternative for consumers and private investors in most market segments. This calls for the development of enabling frameworks to sustain large-scale market-based diffusion, and implies that donor agents and government officials go through a transition from 'project holders' to enabling-framework specialists. In the training and capacity-building provided in the TNA project, we have learned that this transition is difficult at the institutional level as well as on the personal level. Supported by recent research from Thailand (Huenteler et al. 2014) this has encouraged the project to retain its focus on market analysis, measures and enabling frameworks in building capacity.

Secondly, upgrading in the global value chain in terms of the local assembly of panels and local production of other system elements is an opportunity for establishing national systems of innovation for solar PV acknowledged by the TNA project participants. Ensuring adequate and efficient support to this upgrading is a challenge, which will not only be solved by the energy sector, as success will also be contingent on applying a multi-sectorial approach as seen in the TNA project, involving expertise in financing, niche development, learning in firms and technological innovation systems. Researchers, policy-makers and industry both in and outside Africa are currently showing a great interest in following how and to what extent African firms, in collaboration with external partners, will be able to seize this chance for local 'green' business development and local employment. 


\section{References}

Acker, R.H. \& Kammen, D.M., 1996. The quiet (energy ) revolution: analysing the dissemination of photovoltaic power systems in Kenya. Energy Policy, 24(1), pp.81111.

Allali, B., 2011. TEMASOL: Providing Energy Access to Remote Rural Households in Morocco, New York: United Nations Development Programme (UNDP). Available at: http://www.growinginclusivemarkets.org/media/cases/Morocco_Temasol_2011.pdf [Accessed February 13, 2015].

Bazilian, M. et al., 2013. Re-considering the economics of photovoltaic power. Renewable Energy, 53, pp.329-338.

Belward, A. et al., 2011. Renewable energies in Africa. Current knowledge, Joint Research Center, European Commission. Available at: http://publications.jrc.ec.europa.eu [Accessed February 19, 2015].

Bleeker, A.E.M., 2013. Diffusion of Solar PV from a TIS perspective \& its transnational factors. A case study of Tanzania. Thesis. University of Amsterdam. Available at: http://english.rvo.nl/sites/default/files/2014/01/Diffusion of solar PV - A case study of Tanzania.pdf [Accessed February 19, 2015].

Boldt, J. et al., 2012. Overcoming barriers to the transfer and diffusion of climate technologies, Roskilde, Denmark: UNEP Risoe Centre, DTU.

Cîrlig, C.-C., 2013. Solar energy development in Morocco. Library Briefing, Library of the European parliament, pp.1-7.

Coenen, L. \& Díaz López, F.J., 2010. Comparing systems approaches to innovation and technological change for sustainable and competitive economies: an explorative study into conceptual commonalities, differences and complementarities. Journal of Cleaner Production, 18(12), pp.1149-1160.

Dhar, S., Painuly, J.P. \& Nygaard, I., 2010. Organizing the National TNA Process - an Explanatory Note, UNEP Ris $\varnothing$ Centre, Technical University of Denmark. Available at: www.tech-action.org [Accessed February 19, 2015].

DNE, 2011. SREP Mali- Investment Plan: Scaling Up Renewable Energy in Mali: Volume 1, Investment Plan, Direction National de l'Energie de Mali. Available at: http://www.climateinvestmentfunds.org/cifnet/?q=country-program-info/malis-srepprogramming.

ECA and Ramboll, 2012. Technical and Economic Study for Development of Small Scale Grid Connected Renewable Energy in Kenya, London: Economic Consulting Associates (ECA). Available at: http://kerea.org/wp-content/uploads/2012/12/Development-ofSmall-Scale-Grid-Connected-RE-in-Kenya.pdf [Accessed February 19, 2015].

Government of Kenya, 2012. National Energy Policy: third draft, Government of Kenya (GoK). Available at: http://www.kplc.co.ke/img/full/bWXFzkYGyS97_National_Energy_Policy__Third_Draft_-_May_11_2012.pdf.

Hall, M., 2013. PPA for Rwanda's first grid scale solar park. PV magazine. Available at: http://www.pv-magazine.com/news/details/beitrag/ppa-for-rwandas-first-grid-scalesolar-park_100012128/\#axzz2xwaw8W9e [Accessed April 4, 2014].

Hankins, M., 2000. A case study on private provision of photovoltaic systems in Kenya. In P. J. Brook \& S. Smith, eds. Energy Services for the World's Poor: Energy and 
Development Report 2000. Washington: ESMAP, World Bank, pp. 92-99.

Hankins, M., Saini, A. \& Kirai, P., 2009a. Kenya's Solar Energy Market: Target Market Analysis, Berlin: Deutsche Gesellschaft für Technische Zusammenarbeit (GTZ).

Hankins, M., Saini, A. \& Kirai, P., 2009b. Rwanda's Solar Energy Market: Target Market Analysis, Berlin: Deutsche Gesellschaft für Technische Zusammenarbeit (GTZ).

Hansen, U.E., Nygaard, I. \& Pedersen, M.B., 2014. Prospects for investment in large-scale, grid-connected solar power in Africa, Copenhagen: UNEP Risoe Centre. Available at: http://www.uneprisoe.org/ /media/Sites/Uneprisoe/News Item (pdfs)/UNEP RISOE_Prospects for Investment Solar Power_WEB.ashx [Accessed February 13, 2015].

Hansen, U.E., Pedersen, M.B. \& Nygaard, I., 2014. Review of Solar PV market development in East Africa, Copenhagen: UNEP Risoe Centre, Working Paper Series No. 12 March 2014. Available at: http://www.unepdtu.org/PUBLICATIONS/URC-Working-PaperSeries [Accessed February 13, 2015].

Hekkert, M.P.P. et al., 2007. Functions of innovation systems: A new approach for analysing technological change. Technological Forecasting and Social Change, 74(4), pp.413432.

Huenteler, J., Niebuhr, C. \& Schmidt, T.S., 2014. The effect of local and global learning on the cost of renewable energy in developing countries. Journal of Cleaner Production.

Huld, T., Jäger-Waldau, A. \& Szabó, S., 2014. Mapping the cost of electricity from gridconnected and off-grid PV systems in Africa. In 1st Africa Photovoltaic Solar Energy Conference and Exhibition, 27-29 March 2014, Durban, South Africa. pp. 151-155.

IEA, 2013. World Energy Outlook 2013 - Electricity Access Database, OECD/IEA.

Available at:

http://www.worldenergyoutlook.org/media/weowebsite/energydevelopment/WEO2013E lectricitydatabase.xlsx [Accessed February 19, 2015].

Jacobson, A., 2007. Connective Power: Solar Electrification and Social Change in Kenya. World Development, 35(1), pp.144-162.

Jacobsson, R., 2013. The diffusion of solar PV technology using TIS perspective - a case study of Rwanda. PhD Thesis. VU University Amsterdam.

Lundvall, B.- $\AA$. et al., 2002. National systems of production, innovation and competence building. Research Policy, 31(2), pp.213-231.

Magradze, N., Miller, A. \& Simpson, H., 2007. Selling Solar: Lessons from more than a decade of IFC's experience. , p.60. Available at: http://www.ifc.org/wps/wcm/connect/b5c8428048855621b964fb6a6515bb18/SellingSol ar.pdf?MOD=AJPERES [Accessed February 19, 2015].

Maïga, A.I., 2012. Personal communication with Maiga Alhousseini Issa, CNESOLER, Mali in 2012.

ME, 2012. Feed-in-tariffs policy on wind, biomass, small-hydro, geothermal, biogas and solar resource generated electricity, Nairobi: Ministry of Energy (ME) Kenya.

MEAT, 2012. Evaluation des besoins en technologies et plans d'actions technologiques pour l'atténuation des changements climatiques, Mali, Bamako, Mali: Agence Nationale de la Météorologie, Ministère de l'Equipement et de l'Aménagement du Territoire.

MEDD, 2012. Evaluation des besoins en technologies (EBT) et plans d'action technologiques 
(pat) aux fins d'atténuation aux effets du changement climatique, Dakar: Ministère de l'Environnement et du Développement Durable (MEDD). Available at: http://www.techaction.org/index.php?option=com_k2\&view=item\&task=download\&id=97_e003b01940 a3df211828d6a38da453a8 [Accessed February 19, 2015].

MEMEE, 2012. Evaluation des besoins technologiques et plan d'actions technologiques aux fins d'atténuation du changement climatique, Rabat: Ministére de l'Energie, des Mines, de l'Eau et de l'Environnement (MEMEE). Available at: http://www.techaction.org/index.php?option=com_k2\&view=item\&task=download\&id=74_e3313c8ed4 78b622e49b43f05fcf4f3f [Accessed February 19, 2015].

MESD, 2013. Evaluation des besoins en technologies et plans d'action technologiques aux fins d'atténuation de changement climatiques, Côte d'Ivoire, Abidjan: Ministère de l'Environnement, des Eaux et Forêts. Available at: http://www.techaction.org/index.php?option=com_k2\&view=item\&task=download\&id=33_fd073b844e b99711df8487311f8e7194 [Accessed February 19, 2015].

Meza, E., 2013. Special Report Africa: Kenya. PV-Magazine. Available at: http://www.pvmagazine.com/news/details/beitrag/special-report-africa-kenya_100013508/\#axzz2yN8PFzyZ [Accessed February 19, 2015].

Moner-Girona, M. et al., 2006. Decreasing PV Costs in Africa: Opportunities for Rural Electrification using Solar PV in Sub-Saharan Africa. Refocus, 7(1), pp.40-45.

NEMA, 2013. Technology Needs Assessment and Technology Action Plans for Climate Change Mitigation, Kenya, Nairobi: National Environmental Management Authority (NEMA). Available at: www.tech-action.org [Accessed February 19, 2015].

Nygaard, I. et al., 2012. Screening of feasible applications of wind and solar in Mali: Assessment using the wind and solar maps for Mali, UNEP Ris $\emptyset$ Centre, Technical University of Denmark. Available at: www.frsemali.org [Accessed February 19, 2015].

Olson, E.L., 2014. Green Innovation Value Chain analysis of PV solar power. Journal of Cleaner Production, 64, pp.73-80.

Ondraczek, J., 2014. Are we there yet? Improving solar PV economics and power planning in developing countries: The case of Kenya. Renewable and Sustainable Energy Reviews, 30, pp.604-615.

Ondraczek, J., 2013. The sun rises in the east (of Africa): a comparison of the development and status of solar energy markets in Kenya and Tanzania. Energy Policy, 56, pp.407417.

Ondraczek, J., 2011. The Sun Rises in the East (of Africa): A Comparison of the Development and Status of the Solar Energy Markets in Kenya and Tanzania, Working paper. University of Hamburg.

ONE, 2010. Rapport d'Activités 2010, Office Natinale de l'Electricité (ONE). Available at: http://www.one.org.ma/FR/pdf/Rapport_Activités2010.rar [Accessed September 12, 2014].

ONE, 2012. Rapport d'Activités 2012, Office Natinale de l'Electricité (ONE). Available at: www.one.org.ma [Accessed September 12, 2014].

Republic of Rwanda, 2012. Barrier Analysis and Enabling Framework for Technology Transfer and Diffusion, Kigali: Republic of Rwanda. Available at: www.tech-action.org [Accessed February 19, 2015].

Republic of Rwanda, 2000. Rwanda vision 2020, Kigali: Republic of Rwanda. Available at: 
http://www.minecofin.gov.rw/fileadmin/General/Vision_2020/Vision-2020.pdf [Accessed February 19, 2015].

Republic of Rwanda, 2013. Shaping our Development: Economic Development and Poverty Reduction Strategy 2013-2018, Kampala: Republic of Rwanda. Available at: http://www.usaid.gov/sites/default/files/documents/1860/Economic Development and Poverty Reduction Strategy, 2013-2018.pdf [Accessed February 19, 2015].

Reuters, 2014. Rwanda signs $\$ 30 \mathrm{mln}$ deal for $10 \mathrm{MW}$ solar energy plant. Reuters Africa. Available at: http://af.reuters.com/article/rwandaNews/idAFL6N0O22GK20140516 [Accessed February 19, 2015].

Saddouq, A., 2009. Financement PERG, Presentation by Abdessamad Saddouq, ONE at Club ER workshop in Senegal, 15-18 June 2009. Available at: http://www.cluber.org/index.php/en/ressources-et-forum/ressources-documentaires/viewdownload/23financements-et-les-mdp-05-2009/189-1-1-1-financement-du-perg-au-maroc-mabdessamad-saddouq-one-juin-2009.html [Accessed February 16, 2015].

Sarr, S. et al., 2012. Accès aux services énergétiques dans les pays de la CEDEAO : Etudes de Cas, Dakar: Environmental Development Action in the Third World (ENDA).

Seck, L., Niang, G. \& Diagne, M., 2014. Programme national pour le développement de systèmes $P V$ hors réseau (mini-réseaux et systèmes individuels) en zone rurale sénégalaise: Document Nama, Senegal, Maroc: Unpublished draft of NAMA prepared for Direction de l'Environnement et des Etablissements Classés.

SIE-Mali, 2009. Système d'Information Energétique du Mali, Ministère de l'Enérgie et de l'Eau. Direction nationale de l'Enérgie - Système d'Information Energétique (SIE-Mali).

SIE-Mali, 2013. Système d'Information Energétique du Mali, rapport provisoire, Bamako: Direction nationale de l'Enérgie, Ministère de l'Enérgie et de l'Hydraulique.

SIE-Senegal, 2013. Système d'Information Energétique du Sénégal, Dakar: SIE-SENEGAL, Ministère de 1'Energie.

SIE-Senegal, 2010. Système d'Information Energétique du Sénégal - un outil d'aide à la prise de décision, Dakar: SIE - Sénégal, Ministère de la coopération internationale des transports aériens des infrastructures et de l'énergie.

Da Silva, I.P., 2014. Personal communication, 28 March 2014 with Izael Pereira Da Silva, Strathmore University, Kenya.

Taoumi, M., 2008. Les energies renouvelables au maroc, Powerpoint presentation by Mustapha Taoumi, Directeur Conseiller au CDER. Available at:

www.retse.com/old/documentos/ponencia_cder_I.ppt [Accessed February 19, 2015].

UNFCCC, 2013. Third synthesis report on technology needs identified by parties not included in Annex 1 to the convention, United Nations Framework Convention on Climate Change (UNFCCC). Available at: http://unfccc.int/resource/docs/2013/sbsta/eng/inf07.pdf [Accessed February 19, 2015].

WB, 2012. Africa Development Indicators, World Bank (WB). Available at: http://data.worldbank.org/data-catalog/africa-development-indicators [Accessed February 19, 2015].

Willis, B., 2014. Scatec Solar to build East Africa' s first utility-scale PV plant in Rwanda. $P V$-Tech. Available at: http://www.pvtech.org/news/scatec_solar_to_build_east_africas_first_utility_scale_pv_plant_in_rwand a [Accessed June 18, 2014]. 
